\title{
AXIN2 wt Allele
}

National Cancer Institute

\section{Source}

National Cancer Institute. AXIN2 wt Allele. NCI Thesaurus. Code C52464.

Human AXIN2 wild-type allele is located within 17q23-q24 and is approximately $33 \mathrm{~kb}$ in length. This allele, which encodes axin-2 protein, plays a role in the inhibition of the Wnt protein signaling pathway. 